\title{
International Capital Movement towards the Spanish Real Estate Sector
}

\begin{tabular}{|r|l|}
\hline Journal: & Journal of Property Investment \& Finance \\
\hline Manuscript ID & JPIF-05-2019-0067.R3 \\
\hline Manuscript Type: & Academic Paper \\
\hline Keywords: & $\begin{array}{l}\text { International capital flows, Real estate sectors, Foreign investment, } \\
\text { Spain, Vecm models, Panel methods }\end{array}$ \\
\hline \multicolumn{2}{|l}{} \\
\hline
\end{tabular}

\section{SCHOLARONE \\ Manuscripts}




\title{
International Capital Movement towards the Spanish Real
}

\author{
Estate Sector
}

Zhenyu Su \& Paloma Taltavull de La Paz ${ }^{1}$

Department of Applied Economic Analysis, University of Alicante, Spain

\begin{abstract}
Purpose-The purpose of this paper is to examine the macro-economic determinants that affect International Capital Flows towards the Spanish real estate market over the period 1995 first quarter to 2017 fourth quarter.

Design/methodology/approach-A VECM methodology is used to analyse time series and panel methods using pooled EGLS regression.

Findings-VECM parameter results for construction and real estate activities sectors, quickly suggesting a stable performance of capital flows towards the Spanish real estate sector that the short-term fluctuation of foreign investment results contributes to the long-term equilibrium relatively soon. By applying the Monetary Theory of Johnson, the model identifies a relevant role of M3 explaining capital flows to real estate and highlight the time pattern of Spanish real interest rate and Spain's economic growth rate, as significant determinants on international investment to the Spanish real estate sector. Interestingly, Spanish housing prices as an exogenous variable, significantly and negatively affect real estate capital flows in all cases as a way to capture the effect of asset price bubble.

Practical implications-Findings highlight reasons affecting capital flows to real estate and construction activities to Spanish sectors which allow capital funds to take into account those drivers in their investment decisions.

Originality/value-This paper is the first attempt to analyze the determinants of international capital flows to the Spanish real estate market, it is meaningful to those potential international investors.
\end{abstract}

Keywords capital flows, real estate, construction, investment, determinant, Panel, VECM, Spain

Paper type Research paper

\section{Introduction}

International capital movement has been hit hard by the global financial crisis (GFC). However, according to International Monetary Fund (IMF) statistics, and the UNCTAD

\footnotetext{
${ }^{1}$ The authors would express their gratitude to the two anonymous referees of this paper for their useful comment which have contribute substantially to improve this paper.
} 
(2018) World Investment Report, the world economy and global capital flows have both now recovered to pre-crisis levels; the influence of the GFC is waning. In terms of foreign direct investment (FDI), services FDI has increased in recent years and FDI in real estate is expected to increase globally. Evidence of this trend is reflected by the fact that, in recent years, there has been a rapid growth in direct real estate investment (Fereidouni and Masron, 2013). Meanwhile, international investors' confidence has gradually been re-established; many investors have increased their allocation of funds to overseas real estate markets, resulting in a significant surge since 2009, as JLL(2018) report (see Figure 1). Europe has been one of the destinations for this global investment and evidence supports that capital flows towards Europe remained robust during the crisis (Newell et al., 2010).

\section{Figure 1 around here}

Compared to the body of empirical research on the international flows of trade, FDI, and more recently bonds and equities, there has been relatively limited research on cross-border real estate investment flows (McAllister and Nanda, 2014, p. 2). The relationship of property with other investment classes is explained by the portfolio theory (Grissom et al., 2010), allowing investors to reduce the risk of international investments (Haran et al., 2013). In Spain, foreign capital inflows to its real estate market show a steady and increasing trend (see Figure 2) compared to other foreign capital inflows (Rodríguez and Bustillo, 2010), which suggests that the Spanish real estate market represents is a new market for international investors. However, the questions about why the Spanish real estate market has become more attractive to foreign investors, and what determinants are causing this happened, remain unexplained in the existing literature.

\section{Figure 2 around here}

Most of the foreign real estate investment studies have focused on micro indicators like caprate or yields as the main drivers to explain the global capital inflows. However, the traditional economic theories, based on macro-variables to explain the reasons why capital moves among economies, have been relatively explored in the real estate literature. As well 
as following the specific real estate indicators, the large amount of capital seen in Figures 1 and 2 (and their shifts) may possibly have followed macro-economic drivers in terms of decisions on the location in which to enter in the (real estate) sector; in other words, prior to deciding to invest in real estate, the capital flows would test the macro indicators in the area in order to evaluate the potential benefits environment. If so, the macro-economic situation is responsible for the direction of investment flows and could determine whether capital flows into a particular economic sector in an economy. This paper examines this issue: it analyzes and quantifies the role of macroeconomic variables to explain the directions of capital flows and whether or not real estate investment follows similar incentives to FDI in other economic sectors.

The paper is structured as follows: the next section reviews relevant international capital flow theories and foreign real estate investment literature; a description of the modelling and data is presented in section 3; section 4 reports and discusses the empirical analysis results; and section 5 provides conclusions.

\section{Literature review}

\subsection{Theoretical bases of international capital flows}

Many theories have discussed the determinants of international capital flows, this study selects the Flow Theory, the Modern Portfolio Theory, and the Monetary Analysis Theory as theoretical bases to explain the capital flows drivers.

The Flow Theory inherits the economic thought of the Gold Standard. It explains that interest rate is the determinant of international capital movement and that the differences in interest rates among countries cause international capital flows by leading the outflows of domestic capital when foreign interest rate keeps at a high level (the contrary is also true). Meade (1951) proposed the following model to explain the Capital Flow Theory:

Trade balance: $\mathrm{T}=\mathrm{T}(\mathrm{Y}, \mathrm{e} / \mathrm{P})$

Capital flows: $\mathrm{F}=\mathrm{F}\left(i^{D}, i^{F}\right)$ 
International balance of payments (BOP): $\Delta \mathrm{R}=\mathrm{PT}+\mathrm{F}=\mathrm{PT}(\mathrm{Y}, \mathrm{e} / \mathrm{P})+F\left(i^{D}, i^{F}\right)$

Where, $\mathrm{T}$ is trade balance; $\mathrm{Y}$ is the total output; $\mathrm{e}$ is the exchange rate; $\mathrm{P}$ is the price level; $\mathrm{F}$ is capital net flows; $i^{D}$ is the domestic interest rate; and $i^{F}$ is the foreign interest rate; $\mathrm{R}$ is the official reserves. The model suggests that the rise of the domestic interest rate will attract foreign capital inflows when total output and price level are given. Moreover, within the framework of Meade's model, Mundell (1963) and Fleming (1962) developed the MundellFleming model (the IS-LM-BP model) to argue that an economy cannot simultaneously maintain a fixed exchange rate, free capital movement, and an independent monetary policy. They explained that international capital flows are more sensitive to interest rate under a floating exchange rate regime, thus, interest rate is the main factor affecting international capital movement.

The Modern Portfolio Theory (MPT) is first set forth by Markowitz (1952). Tobin (1958) expanded on Markowitz's work by adding a risk-free asset to the analysis and developed the Markowitz-Tobin model. The theory explains that how risk-averse investors can build portfolios to maximize their expected return for a given level of risk. One of the main investors' decisions is to choose assets from different countries as investment targets to spread risk, thus, increasing international capital flows. Branson (1968) believed that long term capital flows are determined by domestic income, domestic interest rate, and foreign interest rate. He added these three factors into the Markowitz-Tobin model and developed a Stock-adjustment model which says that the proportion of foreign assets $(F)$ in a given stock of wealth (W) is a function of domestic and foreign interest rates $\left(I^{D}\right.$ and $\left.I^{F}\right)$, a measure of risk (E), and the stock of wealth (Kouri and Porter, 1974):

$$
F^{f} / \mathrm{W}=\mathrm{f}\left(I^{D}, I^{F}, \mathrm{E}, \mathrm{W}\right)
$$

Under the Stock-adjustment model, investors can allocate their proportion of assets according to the balance between income and risk. When the asset market appears to be supply-demand imbalanced, the actual proportion of assets is not matched with the willing portfolio structure, so the existing portfolio can be adjusted (Li, 2018). Thus, continued international capital flows can occur only as investors' wealth continue to increase, and international capital movement caused by interest rate difference are temporary. 
This theory is key for understanding the specific role of every driver with the interest rate affecting in the short run. In contrast, any wave of increasing global investment flow will push further foreign investment due to risk diversification reasons, contributing to a global investment trend.

The Monetary Analysis Theory (MAT) holds that monetary policy is the main factor affecting international capital flows, which is essentially a monetary phenomenon and determined by domestic monetary policies and international reserve changes. The internal and external capital flows constitute the total state of the balance of payments. Johnson (1972) explained international capital flows by using a model shown below:

Money demand: $M_{d}=p(f y, i)$

Money supply: $\mathrm{M}_{\mathrm{s}}=\mathrm{R}+\mathrm{D}$

Money supply equals to Money demand: $M_{s}=M_{d} \rightarrow R=M_{d}-D$

Reserve changes and the balance of payment: $\mathrm{dR}=\frac{1}{r}\left(\mathrm{dp}+\eta_{y} \mathrm{dy}+\eta_{i} \mathrm{di}\right)-\frac{1-r}{r} \mathrm{dD}$

Where $y$ is real output; $i$ is interest rate; $p$ is the foreign and therefore domestic price level; $\mathrm{R}$ is international reserve; $\mathrm{D}$ is domestic credit; and $r$ is the statutory reserve ratio.

The model indicates that the increasing of real output or the rise of price level will increase the money demand and improve the balance of payment, however, higher interest rate reduces monetary demand and thus worsen the balance of payment ( $\mathrm{Li}, 2018)$. It can be found that this result contradicts the Flow Model, later on, the General Equilibrium Model explains this contradiction and it holds that the level of interest rate determines the shortterm international capital flows, while the long-term movement of capital is affected by the money stock and domestic credit policy (He, 2004).

\subsection{Cross-border real estate capital flows}

Most of the literature focusing on real estate analyzes the role of the returns micro-economic determinant of real estate submarkets, as return indicators, to explain how they act as incentives to drive international capital movements. However, there is little real estate 
literature that focuses on the macro determinants to explain cross-border capital flows.

The traditional focus is to analyze the investment flows following the principles embedded in the portfolio theory. For instance, Lizieri and Finlay (1995) examined the validity of the resulting diversification strategies. Stevenson (2000) examined the potential diversification opportunities arising from the extension of real estate portfolios into an international environment over the period 1978 to 1997 . The results indicated that the improvement in performance is not statistically significant unless a fully hedged currency strategy is adopted, and substantial amounts are allocated in non-domestic markets. Newell and Webb (1996) analyzed real estate, stocks, and bonds in the US, Canada, the UK, Australia, and New Zealand over the period 1985 to 1993 . Their findings showed that, by adjusting for exchange rate variations, all risks profiles for these five markets increased significantly for international investors when adjusting for currency risk.

The role of the significant changes in capital flows affecting real estate has only partially been analyzed. Guo and Huang's (2010) study examined the effect of "hot money" (speculative funds) inflow on the fluctuation of China's real estate and stock markets by using monthly data from January 1997 to October 2008. Their findings demonstrated that the speculative capital flows aggravated the inflated short-term real estate price and enhanced the volatilities of the real estate market in China. They also found that share price shocks generated higher housing prices, whereas real interest rate shocks resulted in tumbling housing prices.

Sirmans and Worzala (2003) provided an extensive literature review of research on international direct real estate investment, focusing on currency risk and diversification benefits through a mixed-asset portfolio and a real-estate-only portfolio, which represent two separate contexts, as currency risk is an important consideration for international investors.

Studies using macroeconomic variables to analyze the flow of capital, however, are scarce. 
Among those seeking to understand the role of general economic variables to explain foreign investment in real estate, Hines (2001) found that economic growth and weak currency in the host country attracted more foreign investment into its real estate market. Li (2003) pointed out that economic development level, interest rates, and housing prices are the major macro-economic factors affecting international real estate investment. Policy, cultural, and social factors were also shown to affect real estate capital flows. Chin et al. (2006) asserted that economic growth has served to draw the attention of international property investors to Southeast Asian markets. The findings of He et al. (2009) demonstrate that foreign investors avoid provinces with high financing and labor costs but significantly favor provinces with higher housing prices in the Chinese context. The same evidence of higher property prices affecting foreign real estate investment was found by Fereidouni and Masron (2013). Falkenbach (2009) studied the market selection criteria in real estate investment in Europe, with findings indicating that market size, taxation, and expected economic growth are the most important economic factors to considered for international investors.

McAllister and Nanda (2014) investigated the determinants of cross-border investment flows between national real estate markets by using a gravity modelling for the period 2007 to 2012, with results indicating that the economic size and distance have expected effects on international real estate capital flows, which is consistent with previous research for trade and FDI. Lizieri and Pain (2014) also found that economic size has a strongly positive effect on cross-border office investments. Furthermore, macro-factors like GDP growth rate, interest rates, exchange rates, inflation rate, risk premium, etc. have also been proven to affect indirect real estate capital flows (Chen et al., 1998; Kola and Kodongo, 2017)

Regarding institutional barriers, Lieser and Groh (2011) and Salem and Baum (2016) demonstrated that political stability is a determinant of foreign direct real estate investment. Regarding the micro variables, profitability, rents, gross operating profit, historical return, lower financing costs, higher levels of transparency in the real estate market, rapid urbanization, market liquidity, and compelling demographics have been proven to impact 
cross-border real estate capital flows (Fereidouni and Masron, 2013; Ford et al., 1998; Fuerst et al., 2015; Lieser and Groh, 2014; Newell and Seabrook, 2005).

\section{Modelling and Data}

The Stock-adjustment model (eq. 4) has been applied to analyzing determinants of international capital flows by many scholars, following Kouri and Porter (1974), after the first difference on both sides of that expression (4), we got a new equation shown below:

$$
\Delta F^{f}=f\left(I^{D}, I^{F}, E, W\right) \Delta W+\left[f_{I^{D}} W \Delta I^{D}+f_{I^{F}} W \Delta I^{F}+f_{E} W \Delta E+f_{W} W \Delta W+\mu\right]
$$

Where $\mu$ is an error term. The result of such transformation gives a first component on the right-hand side measuring the continuing "flow effect" of portfolio growth on capital flows 2 , while the second part "[between brackets]" measures the "stock effect" of portfolio adjustment associated with changes in interest rates and other relevant variables (Kouri and Porter, 1974).Whereas, most of the previous studies have ignored the "flow effects" and focused on the "stock effect".

This paper aims at explaining the reasons that supporting foreign capital inflows to the Spanish real estate sector by applying the Branson's theoretical framework. To do so, a reduced form of the equation (9) is defined to isolate the impact of macro-economic variables to explain the foreign inflows of capital. Wealth has two components affecting investment: the amount of accumulated capital and the capital market value. As this paper focuses on the flow perspective, and accumulated wealth (W) is not observable, the GDP growth rate is used as a proxy of changes on country wealth. A measure of wealth price could be also approached by the prices of the existing capital. Regarding to the focus of this paper on real estate, the housing prices (HP) are used as a proxy of wealth price in this model. Also, some literature links international capital flows to the changes in the global housing price cycle (Favilukis et al., 2012).

\footnotetext{
${ }^{2}$ That is, the effect on changes on wealth associated to the variables in the model.
} 
The Branson theory is complemented with the MAT theory following He (2004) and a measure of Monetary Supply (M3) as an endogenous variable affecting capital flows is included in the model. The logic is that monetary measure serves as a control of the interest rates in the mechanism explaining capital movements.

Finally, as foreign inflows can arrive from different monetary areas, the exchange rate (EXCHR) should be included to control for movements in the exchange markets not due to the mechanism affecting the capital movements.

Formalizing, the model to be empirically tested is given in equation (10):

$$
C F_{i, t}^{\text {flow }}=\alpha_{i}+\sum_{i=1}^{i} \beta_{i} X_{i, t}+\sum_{j=1}^{j} \gamma_{j} Z_{j, t}+\mu_{i, t}
$$

Where CF is capital inflows; $\mathrm{X}$ is a matrix of the endogenous drivers of capital flows, with $X=\left\{\operatorname{rir}^{d}, \operatorname{rir}^{f}, g d p, c r, M 3\right\}, \operatorname{rir}$ being real interest rate, domestic (d) and foreign (f); $c r$ is the Spanish country risk; and M3 is the monetary supply; $\mathrm{Z}$ is a matrix of two ( $\mathrm{j}$ ) exogenous components with $Z=\{\operatorname{exch} r, h p\}$, and having ' $i$ ' as the number of sectors receiving foreign capital flows; $\alpha, \beta$ and $\gamma$ are the parameters to be estimated; and $\mu$ is a measure of error. The description of variables is given in Table 1.

\section{Table 1 around here}

As the total wealth is not included into the equation, the model cannot test the significant differences by capital accumulation in every sector (amount of $\mathrm{W}$ ) but it is possible to identify: (1) the variables better explaining changes in foreign capital inflows, and (2) the significant differences on the influence of every variable into each economic sector receiving international FDI. The measure of country risk used adopted here is the orthodox definition: A country risk premium refers to an increment in interest rates that would have to be paid for loans and investment projects in a particular country compared to a benchmark. In the Eurozone, the reference country is Germany and the risk premium of a country is the 
difference between its 10-year bond and the 10-year German bond (Bernoth et al., 2012).

This model definition assumes that capital movement towards the Spanish real estate market is driven by its 'attractiveness' of the economic sectors to foreign investors determined by its pull factors ${ }^{3}$, that is, the interest rates and its departures from the international interest rates, a measure of country risk and the capital (housing) prices. Such a mechanism is controlled by pull factors or any other drivers which are exogenous to the decisions to invest but affect to them. The pull and push factor theory give an interpretation framework for this model allowing rationally to assign the causes explaining capital inflows. This is relevant for investors' decision taken as the macroeconomic variables are easier (and cheaper) to find and because they give the specific factors supporting the flows which allow for better and sustainable investment decisions to real estate sectors, in Spain.

The data used in this paper comes from the Spanish aggregate databases (Table 1). Capital inflows (CF) are taken from the Payment Balance statistics published in detail by 12 recipient sectors; the domestic interest rate is published by Bank of Spain, and the foreign interest rate used is the US one as most of international transactions are denominated in US dollars ${ }^{4}$; Spanish country risk is calculated as the difference between Spain and German long-term interest rates; Spanish monetary supply is provided by the Bank of Spain as an estimation of the monetary liquidity existing in the Spanish economy while housing prices are published by the Ministry of Fomento.

The analysis period is from 1995Q1 to 2017Q4, for the original data, most of capital flow observations give negative values so as the natural logarithm can't be used, and all the observations have been normalized by applying the Z-Score method. The results of a model

\footnotetext{
${ }^{3}$ Push factors are those common to all countries while pull factors are those country-specific determinants (Fratzscher, 2012).

${ }^{4}$ Due to the purpose of this paper, we analyze global capital flows into the Spanish real estate sector, it's a multilateral investment, American interest rate is the best proxy in this case as any changes of the US interest rate affecting the investment worldwide. Also, most of the international transaction is settled by US dollars, thus, we use the EUR/USD exchange rate here.
} 
based on normalized data are not straightforward but here, the findings have been carefully interpreted. Table 2 presents the data descriptive statistics.

\section{Table 2 around here}

\section{Empirical analysis}

This paper uses Vector Autorregression (VAR) methodology to find evidence of the existence of a causal relationship among foreign capital flows to real estate sectors and its drivers, utilizing a two-step approach. First, a conventional error correction model (VECM) is applied to explain the total inflows of capital and for the two real estate sectors (construction and services), estimated separately. This shows whether the empirical data supports the role of macro-aggregates to explain international capital flows to Spain and the existing differences in drivers to real estate sectors. As the method is estimated using panel data, the cross-relationships with other sectors are considered to better isolate the macro influences to explain the real estate capital flow drivers.

Second, the model estimates the individual effect in every type of recipient sector, focusing both on the construction and real estate services sectors, by using a pool that allows the parameters of capital flows to vary by industrial sectors.

\subsection{First step}

As time-series data is used, a set of test checking for stationarity has been done for all variables before to functional form and method is decided. All but two series ${ }^{5}$ are notstationarity. A battery of panel cointegration test have been estimated and their results indicate that there are cointegration relations among these variables (which vary depending on the selected model as explain bellow), so as consequently, the Pool Vector Error Correction Mechanism (PVECM) is adopted for estimation purposes. The general expression is given by (11).

\footnotetext{
${ }^{5}$ All series have been tested for unit roots with the results of all are I (1) but two are I(0). Test results are available under request.
} 


$$
\Delta c f_{i t}=\Omega_{n}\left[c f_{i, t-1}+\sum_{k=1}^{k} \beta_{k} X_{i, t-1}+c\right]+\sum_{k=1}^{k} \gamma_{k, t-j} \Delta X_{i, t-j}+\Phi_{q} Z_{t}+\varepsilon_{i t}
$$

Which is an expression of the model applied for $i$ cross section (capital recipient economic sectors), $k$ endogenous variables, $q$ exogenous variables, $n$ cointegration relationships, and $j$ lags affecting the short-term equilibrium; $\Omega$ is the convergence parameter for each of the $n$ cointegration relationship ${ }^{6}$; the second right-hand term represents the error correction component (short-run reaction of all variables to explain the changes on capital inflows); the third equation term measures the effect of exogenous variables in the equilibrium. By using this specification, the PVECM allows us identifying the flow effects mentioned in Kouri and Porter (1974) and avoid the recurrent mistakes in the literature which ignore that component. Besides, due to capital flows to different economic branches could be endogenously determined (investors interested in Spain could multiply their flows to multiple sectors following their belief because one is performing well), using panel data permits us to control for those endogenous relationships.

In the first model, equation (11) is estimated by including four cointegration relations which can be interpreted as the stock long-term relationship among the capital flows, Spanish real interest rate, M3, Spanish GDP growth rate, and Spanish country risk, for the whole sample. In the second and third equations, the specific model for construction and real estate services are estimated, with two cointegration relations among variables each found among data. The cointegration identified show the existence of causality in the long-term and stable relations among the variables estimated in each case. Table 3 shows the long-term relationship estimated among the model variables ${ }^{7}$ for full industrial. Every long-term relationship is led by the capital inflows, GDP growth rate, M3, interest rates and country risk $^{8}$. The cointegration equations are shown in Table 3.

\footnotetext{
${ }^{6}$ Each one measure the speed at which the long-term relationships contribute to the short-term equilibrium modelized by the VECM.

${ }^{7}$ The long-term equation is a form to represent an economic mechanism. It takes the form (for instance, regarding the Equation 1) of cf_all $(-1)-0.697 *$ cr_sp $(-1)-0.097=0$ (because is a long-term relationship which tends to the equilibrium. With a bit of algebra, such relationship is transformed in cf_all $(-1)=0.697^{*} \mathrm{cr} \_s p(-1)+0.097$ which suggest the positive effect among both indicators.

${ }^{8}$ The order has been chosen arbitrarily but following the economic logic.
} 


\section{Table 3 around here}

The VECM equations for the whole sample $\left(c f_{i t}\right)$ and 7 lags can be expressed by (12); those for real estate services $\left(c f_{-} r e_{t}\right)$ and construction sector $\left(c f_{-} c o n_{t}\right)$ are shown in (13) and (14) below.

$$
\begin{aligned}
& \Delta c f_{i t}=\Omega_{1}\left[c f_{i, t-1}+\beta_{1} c r_{-} s p_{t-1}+c\right]+\Omega_{2}\left[g d p_{-} s p_{t-1}+\beta_{2} c r_{-} s p_{t-1}+c\right]+\Omega_{3} \\
& {\left[m 3_{t-1}+\beta_{3} c r_{-} s p_{t-1}+c\right]+\Omega_{4}\left[r i r_{-} s p_{t-1}+\beta_{4} c r_{-} s p_{t-1}+c\right]+\sum_{j=1}^{7} \sum_{i=1}^{5} \gamma_{i, t-j} \Delta X_{i, t-n}} \\
& +c+\Phi_{1} e x c h r_{t}+\Phi_{2} \mathrm{~h}_{-} s p_{t}+\varepsilon_{i t}
\end{aligned}
$$

Table 4 shows the results of model (12). It is interesting to see how capital risk is statistically significant in all long-term mechanism identifying the way through which the country risk affects capital inflows to Spain: from Eq1 to Eq3, country risk is negatively associated in the long-term with the total inflows of capital suggesting that any increase on country risk is related to lower capital flows, lower GDP growth rate (that is, periods with economic crisis) and lower amount of available liquidity, which is consistent with the economic logic. Note the strong effect existing with M3 suggesting that the inverse relationship between monetary liquidity and country risk can be understood as that the lower the country risk, the larger the liquidity existing in the economy (that is, liquidity flows towards those economies with less risk associated). The fourth equation (Eq4) registers the interest rate level, which also support the economic principles. Those results are economically consistent and support the robustness of this model.

The base-model estimating the short-term parameters are in Table $4^{9}$. On it, the five equations corresponding to each variable are shown to explain the equilibrium in the whole capital inflows (Eq1), GDP growth (Eq2), M3 (Eq3), real interest rate (Eq4) and country risk (Eq5), by including (in the first four rows of Table 4) the parameters measuring the longterm contribution on the short-term equilibrium of each. The Table also includes the result

${ }^{9}$ Table 4 only contains the statistically significant parameters in order to avoid a long table. Full results are available under request. 
of exogenous variables parameters. It is interesting to see how the PVECM register as statistically significant the first and the third mechanism to explain changes on capital flows suggesting that capital flows converge based on the long-term relationship of itself, and diverge with M3 relationship, that is, the monetary liquidity seems to exacerbate permanently the changes on capital flows. Besides, interest rates mechanism affects (making them converge) to other three equations. Short-term country risk equation does not depend on any of the long-term mechanism achieving its equilibrium in the very short term ${ }^{10}$.

\section{Table 4 around here}

Our equation of interest is the capital inflows (Eq1). The regression results give an adjusted $\mathrm{R}^{2}$ of 0.481 , suggesting almost half of the variation in international capital flows to the 18 Spanish economic sectors could be explained by the selected variables. This explanatory capacity is the result of the impact of a few numbers of variables: the long-term mechanism (with permanent effects) as well as the short-term components (with temporary effect) explained below. The convergence coefficient (capital flows associated with country risk) is -0.869 , and it is statistically significant at $1 \%$ level which suggest the existence of a slow process of convergence when a shock affect to capital flows the Spanish industrial sectors, that is, the long-term equilibrium of capital flows does not contribute to a fast adjustment in the short run, showing periods of instability (in both signs). The interpretation suggests ${ }^{11}$ that any increase on country risk is associated to lower capital flows permanently, and its effects adapting short-term changes on the latter are very slow.

Short-term changes in capital flows (with temporary effects) only react to the first and the fifth lag of Spain's economic growth, and first and fourth lags of changes on monetary supply-M3 ${ }^{12}$. The latter affects capital flows change significantly, showing an immediate effect, and one year later. The parameter value of monetary liquidity suggests that one point of increase in the previous (one lag) change of M3 value leads to 1.9 points of increase in

\footnotetext{
${ }^{10}$ The sensibility captured in the model is due to the time pattern exhibit by country risk itself. ${ }^{11}$ Gujarati and Porter, 2009.

${ }^{12}$ One can assume that M3 and GDP could show a long-term relationship explaining this association, but the cointegration tests performed reject the null of the existence a long-term association.
} 
the current total capital inflows (plus 1.5 points if the shock was in the fourth lag). Due to the data being in normalized values, the interpretation of results could be explained as an increase of one standard deviation in M3 four lags before increases of 1.5 standard deviation in capital flows and 1.9 standard deviation one lag before. In short, the volatility in capital flows is multiplied by more than three due to an increase in the M3 volatility.

It is important to note that this equation records a relevant impact on capital flows coming from the Spanish housing prices with a negative contribution at 1\% level. This suggests that, during the analyzed period, an increase in Spanish housing prices by one standard deviation ${ }^{13}$ contributes negatively to the short-term equilibrium of the capital flows by reducing on average 0.41 standard deviations in their changes in the short run. Such a result can be interpreted as highlighting the opportunistic effect of international investment: the lower level of Spanish wealth (measured through housing prices), possibly resulting from the internal devaluation (due to the period analyzed, after the GFC), leads to capital funds perceiving an opportunity to invest in the market, thus increasing international capital flows.

The rest of the model results [from (2) to (5); see Table AI in the Appendix] show economic reactions in the model that are consistent with the economic logic and previous research.

The second model focuses on the mechanism of driving capital flows for the Spanish construction and real estate services sectors.

$$
\begin{aligned}
& \Delta c f_{-} r e_{t}=\Theta_{1}\left[c f_{-} r e_{t-1}+\lambda_{1}^{1} m 3_{t-1}+\lambda_{2}^{1} r i r_{-} s p_{t-1}+\lambda_{3}^{1} c r_{-} s p_{t-1}+c\right]+\Theta_{2} \\
& {\left[g d p_{-} s p_{t-1}+\lambda_{4}^{1} r i r_{-} s p_{t-1}+\lambda_{5}^{1} c r_{-} s p_{t-1}+c\right]+\sum_{j=1}^{7} \sum_{i=1}^{5} \delta_{k, t-j}^{1} \Delta X_{i, t-n}+c+\psi_{1}^{1} e x c h r_{t}+\psi_{2}^{1} \mathrm{~h}} \\
& p_{-} s p_{t}+v_{t}^{1} \\
& \Delta c f_{-} \operatorname{con}_{t}=\Upsilon_{1}\left[c f_{-} \operatorname{con}_{t_{-1}}+\lambda_{1}^{2} m 3_{t_{-1}}+\lambda_{2}^{2} \operatorname{rir}_{-} s p_{t-1}+c\right]+\Upsilon_{2}\left[g d p_{-} s p_{t-1}+c\right]+ \\
& \sum_{j=1}^{7} \sum_{i=1}^{5} \delta_{k, t-j}^{1} \Delta X_{i, t-n}+c+\psi_{1}^{1} e x c h r_{t}+\psi_{2}^{1} \mathrm{~h} p_{-} s p_{t}+v_{t}^{2}
\end{aligned}
$$

Table 5 presents the results of the long-term relationship evidenced by the Johansen tests of panel cointegration. For real estate services capital flows, the long-term relationship

\footnotetext{
${ }^{13}$ As the exercises are performed based on standardized data through Z-scores.
} 
indicates a strong mechanism among the endogenous variables, where inflows are associated positively with country risk and negatively with M3 and interest rates. The signs are consistent with the previous general models and, strictu sensu, this long-term relationship suggests that a unit of capital inflow in real estate services in Spain is associated with low liquidity $(-1.7)$, lower interest rates $(-0.9)$, and with larger country risk $(0.7)$; that is, the large country risk leads to inflows in Spanish real estate sectors when interest rates are low and a smaller amount of monetary liquidity is available, with permanent effects. The second long-term relationship affecting the model confirms the GDP-country-risk relationship already obtained in the general model above.

Construction sector capital inflows show different long-term mechanism affecting capital movements. In this case, the equation 1 shows strongly association of capital flows with monetary liquidity (negative sign and $1 \%$ of statistical significance) and positively with the interest rates; those suggest that the larger interest rates and the lower liquidity amount, the larger inflows for construction. In this case, the country risk does not appear to be statistically significant in the long term.

\section{Table 5 around here}

Only for the real estate service model did the two long-term relationships contribute to the equilibrium (Table 6), being statistically significant at 1\%, suggesting the existence of a permanent effect from the foreign capital flow and the GDP equations. However, this contribution is also slow ( -0.64 and -0.56 , consistent with the general results) to reach the short-term equilibrium, implying that such slowness can influence short-term disequilibrium in some periods. This mechanism shows several sources of changes in the short run affecting capital flows, for example: real estate flows show a short-term persistency from the previous year (fifth lag=-0.47), suggesting that one standard deviation in the capital flows in the previous period reduces 0.471 standard deviations in the current period; or that a shock on an increase of ten euros of capital flows five quarters ago results in -4.71 euros $^{14}$ in the

\footnotetext{
${ }^{14}$ The second column in Table VI contains the converted parameters. As the model is estimated using normalized data,
} 
current period.

\section{Table 6 around here}

Foreign investment in the real estate sector is strongly affected by general economic growth, with very large parameters [1.6 immediately after ( 1 quarter) and 0.9 with a year of distance (five quarters)], suggesting that any shock increasing the Spanish economy real growth rate results in an immediate rise in the capital flows in the very short term, and persist one year later, showing a large sensitivity. This result is relevant in two senses. First, the two lagged parameters are positive, which means that economic growth positively affects capital flows in the same way, stressing the capital movement towards real estate activities in a procyclical way. Note that the effect is not significant for the flows towards construction activities. Second, this result is significant in terms of the size of the effect. Taking into account the large standard deviation of capital inflows (Table 2), meaning high volatility, interpreting the impact of the estimated parameters is difficult. The result suggests that the acceleration of real Spanish economic growth rate by one basic point ( $1 \%$ of real increase) stresses the capital inflows to real estate by almost 307.5 million euros in the following year (112.1 million in the next five quarters and 195.4 million euros in the next quarter). The sensitivity of this sector to changes in economic growth reveals the significant presence and interest of international real estate companies in the Spanish sector.

The third short-term source of changes is the variation of monetary supply, positively affecting capital flows from the fourth-lag, i.e. an increase in one standard deviation in M3 (normalized value) on average leads to an increase 4.6 standard deviations of capital flows towards the real estate services sector, i.e. one euro more of available liquidity (M3) causes real estate capital inflows in Spain to increase by 4.8 euros. The size of this effect is quite high, consistent with the previous results (in the whole model), suggesting that any monetary policy that results in an increase in liquidity in the short run across the Spanish economy

the parameters are converted in the conventional $\beta$ by the formula $\beta_{i}^{*}=\beta_{i}\left(\frac{S x_{i}}{S y_{i}}\right)$, where $S x_{i}$ are the standard deviations for each dependent variable and $\mathrm{Sy}_{\mathrm{i}}$ are the standard deviations for each independent variable (Gujarati and Porter, 2009). 
strongly affects the capital attraction to its real estate sector. Such an increase has temporary effects on the capital inflows ${ }^{15}$, showing a short-term response of this activity to the monetary shock.

The fourth source of change is the interest rates effect. The estimated parameter finds that any positive shock in interest rates negatively affects real estate flows of capital to the Spanish real estate sector, lagged three periods. That is, an increase of one basic point in real interest rates $(+1 \%)$ reduces the real estate capital inflows by 100.3 thousand euros during the following three quarters. The effect of the shock is lagged and strong.

Finally, the strong estimated effect of housing prices on this sector supports the above results by negatively affecting real estate inflows. The estimated parameter $(-0.712)$ transformed (465.86) suggests the strong impact of housing prices on capital inflows: a rise of price by one euro per square meter leads to real estate capital inflows falling by more than one thousand euros (465.86 euros). The effect seems to be small, but the significance and consistency of these results suggest that the foreign investors look for purchase opportunities based on the market price (the lower the price, the larger the capital flow).

The results for the short-term model of foreign inflows in the construction sector are also shown in Table 6 and reflect a quite different mechanism. In this case, the parameter of thelong-term equation component is statistically significant, suggesting the equilibrium convergence of capital flows to construction activities in the short-run; no remaining shortterm effects appear, but the interest rates effect in the fourth lag is significant in two senses ${ }^{16}$. The size of the effect is consistent with the one found for real estate capital inflows, but with the opposite sign, and suggests that any increase of one basic point in real interest rates increases the construction capital inflows by 205.2 thousand euros during the following four

\footnotetext{
${ }^{15}$ This effect is neutralized in the long term, following equation (1).

${ }^{16}$ Full results of the VECM model include the equation for all the endogenous variables. The interest rates equation shows a large effect with construction inflows. Results are available on request.
} 
quarters. This result seems to be a kind of substitution effect between both sectors, with capital allocate in construction when interest rates rise rather than in real estate. These findings show that capital flows to construction do not have persistence, suggesting they represent an occasional effect (in Spanish market) closely related to changes in interest rates.

Housing prices are statistically significant with a consistent and stronger effect on this type of investment (parameter $=1.249$ ), suggesting that this could strongly affect investment in construction (building) with a greater effect $\left(\beta^{*}=-1.25, \beta=-1135.89\right)$.

\subsection{Second step}

The differences in the sensitivity of every capital flow depending on the sector addressed raises the question of whether the same macroeconomic factors would affect capital flows to real estate following different patterns to the rest of the economy. To test this hypothesis, a new model specification was created THAT allows the coefficient explaining capital flows by sector to vary by each macro-economic variable demonstrated above to have a statistically significant effect (GDP growth rate, M3, and housing prices). The functional form adopts now a matrix form as equation (15).

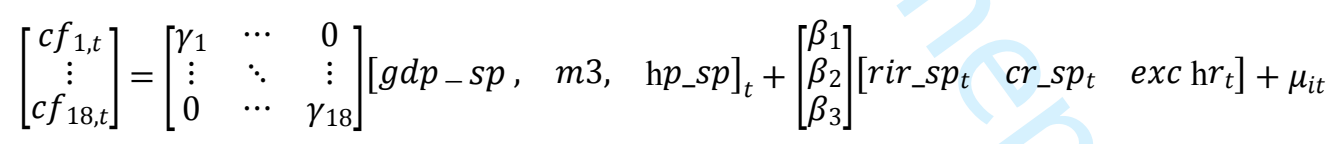

The model (15) is estimated using pooled EGLS regression tool in (normalized data) levels approaching the long-term effects of the related variables and letting the 18-different industrial inflows parameters to change with three key indicators (GDP growth rate, M3 and housing prices index) in order to capture their specific influence in every sector and focus on the results of construction and real estate services capital flows. Note that, in this case, housing prices index, GDP growth rate, and M3 are analyzed as cross-section specific coefficients and Spanish real interest rate, Spanish country risk and exchange rate are included as a common-endogenous coefficient. For the estimation method, no fixed or 
random effects are included ${ }^{17}$ and the estimation includes cross-section weights. The result is reported as below in Table 7 .

\section{Table 7 around here}

As shown in Table 7, the total model has an adjusted $\mathrm{R}^{2}$ of 0.087 , showing a lower explanatory power, although it does capture all cross-section relationships and does not leave any remaining information in the residuals. The parameters identify the unobserved heterogeneity among the sectors' capital flows and their different reactions relative to the changes in macroeconomic variables. Results suggest that capital flows react to GDP real change rate only in only a few sectors, two of which are in our intersect - sector 1 (agriculture, forestry, and fishing), sector 6 (construction), sector 12 (real estate activities (positively)), and sector 17 (arts, entertainment, and recreation (negatively)) - capturing the reaction of these specialized flows to Spanish economic growth. For sectors 6 and 12, the sensitivity of capital inflows is larger than in most of the other sectors, consistent with the results in the previous models and supporting the idea that real estate international flows are quite sensitive to economic growth, independently of other particular economic drivers.

The reactions to monetary liquidity are broad in a large number of sectors ${ }^{18}$. Again, the real estate services sector (12) shows the larger reaction to variations of M3 (with a parameter of $1.285)$ and the construction sector (6) shows the third larger effect (0.99), suggesting that capital inflows addressing real estate are more sensitive than others to monetary conditions. Any change in monetary policy has large effects on inflows of foreign capital to real estate in Spain.

This result is in accordance with the general theories of international capital flows: any increase in monetary supply leads to an increase in the capital to invest (MAT theory; see

\footnotetext{
${ }^{17}$ Random effect is rejected in favour of fixed effects but after its estimation, the Redundant Fixed Effect test cannot reject the null.

${ }^{18}$ Sector 1,6,9 (accommodation and food service activities) and 12,13 (professional scientific and technical activities) at $1 \%$ of significance, and sectors 3 (manufacturing), 5 (water supply, sewerage, waste management and remediation activities), 11 (financial and insurance activities), 15 (education), 16 (human health and social work activities), and 17 (arts, entertainment and recreation) at 5\% of significance.
} 
$\mathrm{He}, 2004)$ and in the amount of capital available for portfolio allocation. Due to risk aversion, portfolios tend to invest abroad (MPT theory) to diversify the risk. The empirical evidence here supports that this is true for the Spanish case and that the most sensitive sector is real estate (and construction). Because the analyzed period covers the introduction of the euro (1999) in the general model and the beginning of the quantitative easing policy by the European Central Bank (2014), the model may capture the effects of the rise in monetary liquidity due to integration, which would have had direct effect on the domestic real estate sector, modifying the mechanism. This effect is more relevant in real estate than construction and reflects the reasons for the rapid internationalization experienced by the real estate sector after the GFC.

Finally, housing prices are also broadly (negatively) related to the flows of capital through the changes in inflows in several sectors: sectors $1,3,6,12$, and 17 at $1 \%$ of significance; and sectors 9,10 , and 13 at 5\%. Again, the largest sensitivity appears in the real estate market, followed by the real estate services sector $(-0.839)$ and the construction sector $(-0.577)$, suggesting that the interpretation above is correct and foreign capital inflows react negatively when Spanish housing markets (as a reflection of the national capital wealth) rise.

The price attractiveness (after a strong contraction in property prices during 2009-2014) for foreign investors is well captured by these results, suggesting that any increase in prices during the recovery will reduce the flow of capital received by Spanish real estate. However, the quantitative easing policy still being applied by the ECB could be one of the reasons for the large appetite of foreign funds for Spanish real estate, despite the price recovery.

\section{Conclusion}

The purpose of this study is to investigate the effects of the macro-economic determinants of foreign flows of capital allocation in the Spanish real estate sector. A model is designed based on the principles of flow, monetary, and portfolio theories for international capital movement by using macro-economic determinants to explain capital inflows to the real 
estate sector in Spain.

The model includes 18 investment industrial sectors over 1995(Q1) to 2017(Q4) and the analysis is performed by applying VAR-panel methods to test different hypotheses and quantify the relevance of macro-variables to explain international capital flows, the differences among drivers leading capital flow to real estate, and the size of the effect of every variable on real estate capital inflows (in Spain). The cointegration test and VECM models show the existence of four long-term relationships in the general inflows model and two specific inflows in the real estate services and construction model, suggesting the existence of long term-relationships among the variables that display permanent effects.

The paper finds a persistent and systematic reaction of foreign inflows in Spain, showing consistent time patterns related to the Spanish economic real growth rate, monetary liquidity (M3), and interest rates, and also showing a general reaction to housing prices (but not to exchange rates), with the latter two being considered exogenous to the system (following the theory). Country risk is statistically significant in the long term, but the evidence does not show that short-term changes in country risk (neither in the general model nor the real sector or construction models) could mobilize foreign capital flows, suggesting that the capital inflows to Spanish economy follow stable paths linked to economic activities. On the contrary, the evolution of GDP is strongly significant in the short run to explain capital movement (both in general and real estate, but not in construction) with a no-convergence influence, which stresses capital flows as the Spanish economy growth. The fast and persistent sensitivity of foreign inflows to Spanish economic growth is a strong finding here, suggesting that the growth in the Spanish economy is the trigger for capital inflows into Spanish industrial sectors.

Monetary liquidity (M3) also shows a strong and persistent influence on general foreign inflows, especially in real estate capital flows to Spain. This finding supports the monetary analysis theory developed by Johnson (1972) and provides empirical evidence of the 
relevance of monetary markets in explaining capital movement. The overreaction shown by real estate is interpreted as how changes in the monetary market during the analyzed period would have played a role in its internationalization, together with a price incentive coming from the constraints on Spanish property prices after the GFC. Finally, exchange rates are not found to show any effect on capital movement.

This paper's findings have important implications for the investors. First, the combination of macro-variables and their time patterns (persistency and memory) can explain almost a half of the total flows, suggesting that these variables should be considered when companies decide on investment allocation. Second, the association with Spanish economic growth suggests that the flow of capital to real estate will rise when GDP growth rate increases; the capital accumulation potentially increases the willingness to buy Spanish buildings, raising prices. Finally, the strong role of monetary liquidity found in the results suggests that the expansive monetary policy is favoring the increased flow of capital towards Spanish real estate independently of other real estate indicators. In consequence, investors could forecast the effect on international capital flows following the monetary policy and, especially, estimate the effects of the finalization of quantitative easing policy in the European Monetary Union.

This study is an attempt to compare the determinants of international capital flows towards the Spanish real estate sector that exist in the theories and previous literature. However, the results of this paper should be considered in light of its limitations, which also point to areas for future research, relative to data and the time evidence.

\section{References}

Bernoth, K., Hagen, J. and Schuknecht, L. (2012), "Sovereign risk premiums in the European government bond market", Journal of International Money and Finance, Vol.31 No.5, pp.975-995.

Branson, W. H. (1968), Financial Capital Flows in the US Balance of Payments, NorthHolland Publishing Co., Amsterdam. 
Chen, S. J., Hsieh, C., Vines, T. and Chiou, S. N. (1998), "Macroeconomic Variables, FirmSpecific Variables and Returns to REITs", Journal of Real Estate Research, Vol.16 No.3, pp.269-278.

Chin, W., Dent, P. and Roberts, C. (2006), “An exploratory analysis of barriers to investment and market maturity in Southeast Asian cities", Journal of Real Estate Portfolio Management, Vol.12 No.1, pp.49-58.

Falkenbach, H. (2009), "Market selection for international real estate investments", International Journal of Strategic Property Management, Vol.13 No.4, pp.299-308.

Favilukis, J., Kohn, D., Ludvigson, S. C. and Van Nieuwerburgh, S. (2012), "International Capital Flows and House Prices: Theory and Evidence", Housing and the financial crisis, University of Chicago Press, pp.235-299.

Fereidouni, H. G. and Masron, T. A. (2013), "Real estate market factors and foreign real estate investment”, Journal of Economic Studies, Vol.40 No.4, pp.448-468.

Fleming, J. M. (1962), "Domestic financial policies under fixed and under floating exchange rates”, Staff Papers, Vol.9 No.3, pp.369-380.

Ford, D. A., Fung, H. and Gerlowski, D. A. (1998), "Factors affecting foreign investor choice in types of US real estate", Journal of Real Estate Research, Vol.16 No.1, pp.99-111.

Fratzscher, M. (2012), “Capital flow, push versus pull factors and the global financial crisis", Journal of International Economics, Vol.88 No.2, pp.341-356.

Fuerst, F., Milcheva, S. and Baum, A. (2015), "Cross-Border Capital Flows into Real Estate", Real Estate Finance, Vol.31 No.3, pp.103-122.

Grissom, D. N and Porter, D. C. (2010), "Economics of development strategies utilising option and portfolio analytics", Journal of European Real Estate Research, Vol.3 No.2, pp.117-137.

Gujarati, D. N. and Porter, D. C. (2009), Basic Econometrics, 5 ${ }^{\text {th }}$ ed., McGraw-Hill/Irwin, New York, NY.

Guo, F. and Huang, Y. S. (2010), "Does 'hot money' drive China's real estate and stock markets?”, International Review of Economics \& Finance, Vol.19 No.3, pp.452-466.

He, Z. R. (2004), Principles of international finance, Southwestern University of Finance and Economics Press, Chengdu.

He, C., Wang, J. and Cheng, S. (2009), “What attracts foreign direct investment in China's real estate development?", The Annals of Regional Science, Vol.46 No.2, pp.267-293.

Hines, M.A. (2001), Investing in International Real Estate, Greenwood Publishing Group, Portsmouth, NH.

Haran, M., Davis, P., McCord, P. D., Grissom, T. and Newell, G. (2013), "Equities or real estate? An international evaluation of listed property markets", Journal of European Real 
Estate Research, Vol.6 No.2, pp.139-162.

International Monetary Fund (IMF) statistics, available at https://data.imf.org

JLL (2018), Quarterly global transaction volumes, available at: https://www.theinvestor.jll/gcf/.

Johnson, H. G. (1972), “The Monetary Approach to Balance-of-Payments Theory”, Journal of Financial and Quantitative Analysis, Vol.7 No.2, pp.1555-1572.

Kola, K. and Kodongo, O. (2017), "Macroeconomic risks and REITs returns: A comparative analysis", Research in International Business and Finance, Vol.42, pp.1228-1243.

Kouri, P. J. K. and Porter, M. G. (1974), "International Capital Flows and Portfolio Equilibrium”, Journal of Political Economy, Vol.82 No.3, pp.443-467.

Li, D. (2018), “An Economic Analysis of International Capital Flow”, American Journal of Industrial and Business Management, Vol. 8, pp.404-416.

Li, W. B. (2003), "Development Characteristics and Influencing Factors of International Real Estate Investment", Journal of University of International Business and Economics, Vol.1, pp.69-83.

Lieser, K. and Groh, A. P. (2011), “The attractiveness of 66 countries for institutional real estate investments", Journal of Real Estate Portfolio Management, Vol.17 No.3, pp.191-211.

Lieser, K. and Groh, A. P. (2014), "The Determinants of International Commercial Real Estate Investment", The Journal of Real Estate Finance and Economics, Vol.48 No.4, pp.611-659.

Lizieri, C. and Finlay, L. (1995), "International property portfolio strategies: problems and opportunities”, Journal of Property Valuation and Investment, Vol.13 No.1, pp.6-21.

Lizieri, C. and Pain, K. (2014), "International office investment in global cities: The production of financial space and systemic risk", Regional Studies, Vol.48 No.3, pp.439-455.

Markowitz, H. (1952), "Portfolio selection”, The Journal of Finance, Vol.7 No.1, pp.77-91.

McAllister, P. and Nanda, A. (2014), "Which Factors Determine Cross-Border Real Estate Capital Flows? A Gravity Modelling Approach", SSRN working paper, available at: https://ssrn.com/abstract=2417559 (accessed: 30 March 2014).

Meade, J. E. (1951), The Theory of International Economic Policy: The balance of payments, Oxford University Press, London.

Mundell, R. A. (1963), “Capital Mobility and Stabilization Policy under Fixed and Flexible Exchange Rates”, Canadian Journal of Economics and Political Science, Vol. 29 No.4, pp.475-485.

Newell, G. and Webb, J. (1996), “Assessing Risk for International Real Estate Investment”, Journal of Real Estate Research, Vol.11 No.2, pp.103-115. 
Newell, G. and Seabrook, R. (2005), "Factors influencing hotel investment decision making", Journal of Property Investment \& Finance, Vol.24 No.4, pp.279-294.

Newell, G., Adair, A. and McGreal, S. (2010), "Robustness of capital flows into the European commercial property markets during the global financial crisis", Journal of European Real Estate Research, Vol.3 No.3, pp.182-202.

Rodríguez, C. and Bustillo, R. (2010), "Modelling foreign real estate investment: the Spanish case", Journal of Real Estate Finance and Economics, Vol.41 No.3, PP.354-367.

Salem, M. and Baum, A. (2016), "Determinants of foreign direct real estate investment in selected MENA countries", Journal of Property Investment \& Finance, Vol.34 No.2, pp.116-142.

Sirmans, C. F. and Worzala, E. (2003), "International direct real estate investment: a review of the literature”, Urban Studies, Vol. 40 Nos. 5-6, pp. 1081-1114.

Stevenson, S. (2000), "International real estate diversification: empirical testes using hedged indices”, Journal of Real Estate Research, Vol.19 No.1, pp.105-131.

Tobin, J. (1958), "Liquidity preference as behaviour towards risk", The review of economic studies, Vol.25 No.2, pp.65-86

UNCTAD (2018), "World Investment Report 2018: Investment and New Industrial Policies", available at: https://doi.org/10.18356/ebb78749-en (accessed: 07 June 2018). 


\section{TABLES}

Table 1: DESCRIPTION OF VARIABLES

\begin{tabular}{cllc}
\hline Variables & \multicolumn{1}{c}{ Description } & \multicolumn{1}{c}{ Source } & Data Period \\
\hline Cf $f_{i}$ & $\begin{array}{l}\text { Capital flows to Spain } \\
\text { different economic sectors ' } i^{\prime}\end{array}$ & $\begin{array}{l}\text { Ministry of industry, trade } \\
\text { and tourism of Spain }\end{array}$ & 1995Q1-2017Q4 \\
\hline rir_sp & Spanish real interest rate & Bank of Spain & 1995Q1-2017Q4 \\
\hline rir_us & American real interest rate & Bank of Spain & 1995Q1-2017Q4 \\
\hline cr_sp & Spain country risk premium & European Central Bank & 1995Q1-2017Q4 \\
\hline M3 & Monetary aggregate & Bank of Spain & 1995Q1-2017Q4 \\
\hline gdp_sp & GDP growth rate of Spain & Bank of Spain & 1995Q1-2017Q4 \\
\hline exchr & $\begin{array}{l}\text { Exchange rate (euro against } \\
\text { US dollar) }\end{array}$ & Bank of Spain & 1995Q1-2017Q4 \\
\hline hp_sp & Spanish housing prices index & Spanish statistical office & 1995Q1-2017Q4 \\
\hline
\end{tabular}


Table 2: DESCRIPTIVE OF STATISTICS

\begin{tabular}{|c|c|c|c|c|c|c|}
\hline Variables & Mean & Median & Max. & Min. & Std. Dev. & Obs. \\
\hline cf_1- agriculture, forestry and fishing & 25622.74 & 8732.395 & 448898.0 & -64559.52 & 66486.23 & 92 \\
\hline cf_2- mining and quarrying & 22553.88 & 3252.205 & 775721.6 & -99548.62 & 88584.34 & 92 \\
\hline cf_3-manufacturing & 488103.9 & 317328.1 & 4783775 & -3251056 & 930996.1 & 92 \\
\hline cf_4- electricity, gas, steam and air conditioning supply & 453120.9 & 17346.68 & 17712189 & -857303.5 & 2049882 & 92 \\
\hline cf_5- water supply, sewerage, waste management and remediation activities & 19242.22 & 154.000 & 600150.0 & -45338.75 & 87435.19 & 92 \\
\hline cf_6- construction & 205871.0 & 91679.23 & 3330574 & -113896.5 & 417979.4 & 92 \\
\hline cf_7- wholesale and retail trade, repair of motor vehicles and motorcycles & 327646.4 & 128139.5 & 12696614 & -545311.2 & 1344358 & 92 \\
\hline cf_9 - accommodation and food service activities & 55854.03 & 24767.24 & 611308.3 & -73862.29 & 101225.7 & 92 \\
\hline cf_10 - information and communication & 32492.68 & 41416.80 & 589022.0 & -720082.5 & 192052.5 & 92 \\
\hline cf_11 - financial and insurance activities & 194148.0 & 151352.0 & 1866443 & -2613713 & 622021.4 & 92 \\
\hline cf_12 - real estate activities & 213656.7 & 105850.3 & 1816071 & -296811.3 & 300714.7 & 92 \\
\hline cf_13 - professional scientific and technical activities & 80008.03 & 45432.89 & 871433.9 & -1238161 & 234911.0 & 92 \\
\hline cf_14 - administrative and support service activities & 20379.65 & 28146.68 & 457790.2 & -724436.5 & 155503.8 & 92 \\
\hline cf_15 - education & 11632.81 & 1087.920 & 484072.0 & -273014.0 & 71428.31 & 92 \\
\hline cf_17 - arts, entertainment and recreation & 25834.44 & 7873.880 & 481826.8 & -514262.6 & 96504.22 & 92 \\
\hline cf_18 - other service activities & 7618.399 & 569.975 & 251682.9 & -146524.6 & 39141.75 & 92 \\
\hline rir_sp - Real Spanish interest rates & 0.624 & 0.426 & 5.523 & -2.870 & 1.931 & 92 \\
\hline rir_us - Real US interest rates & 1.959 & 1.689 & 8.236 & -2.473 & 1.829 & 92 \\
\hline cr_sp - Spanish country risk & 1.191 & 0.602 & 5.070 & 0.010 & 1.365 & 92 \\
\hline M3 - Monetary Supply & 821079.1 & 880903.0 & 1195899 & 376192.2 & 288030.7 & 92 \\
\hline gdp_sp - Spanish GDP real terms & 2.228 & 3.137 & 6.499 & -4.222 & 2.471 & 92 \\
\hline Exchr-Exchange rates between dollar and euro & 1.208 & 1.249 & 1.562 & 0.869 & 0.160 & 92 \\
\hline hp_sp - Spanish housing prices & 1385.713 & 1491.250 & 2101.400 & 670.800 & 459.599 & 92 \\
\hline
\end{tabular}




\section{Table 3: PANEL LONG TERM RESULTS FOR ALL CAPITAL FLOWS}

\begin{tabular}{|c|c|c|c|c|}
\hline \multicolumn{6}{|l|}{ Long-term relationship: All capital flows, 1995Q1-2017Q4 } \\
\hline Variables & Eq1 & Eq2 & Eq3 & Eq4 \\
\hline Capital Flows (t-1) & 1.000 & 0.00 & 0.00 & 0.00 \\
\hline GDP growth rate (t-1) & 0.00 & 1.000 & 0.00 & 0.00 \\
\hline M3(t-1) & 0.00 & 0.00 & 1.000 & 0.00 \\
\hline Real Interest Rate (t-1) & 0.00 & 0.00 & 0.00 & 1.000 \\
\hline Country Risk (t-1) & $-0.697^{* * *}$ & $-0.079^{* * *}$ & $-2.046^{* * *}$ & $0.919^{* * *}$ \\
& $(0.0659)$ & $(0.0236)$ & $(0.1041)$ & $(0.0821)$ \\
\hline Constant & -0.097 & 0.004 & -0.332 & 0.250 \\
\hline
\end{tabular}

Note: The variables with (t-1) means that the flows are lagged one period $* * \mathrm{p}<0.05$ and $* * * \mathrm{p}<0.01$, standard errors are in brackets. 
Table 4: Pool-VECM results for all capital flows, 1995Q1-2017Q4

\begin{tabular}{|c|c|}
\hline Error Correction: & $\Delta \mathbf{C F}$ \\
\hline Equation & (1) \\
\hline CointEq1-capital flows & $-0.869 * * *(0.060)$ \\
\hline CointEq3-M3 & $0.333 * * *(0.042)$ \\
\hline$\Delta$ GDP growth rate ${ }_{t-1}$ & $0.410 * * *(0.144)$ \\
\hline$\Delta$ GDP growth rate ${ }_{t-5}$ & $0.432 * * *(0.122)$ \\
\hline$\Delta \mathrm{M} 3_{\mathrm{t}-1}$ & $1.979 * *(0.839)$ \\
\hline$\Delta \mathrm{M} 3_{\mathrm{t}-4}$ & $1.564 * *(0.789)$ \\
\hline $\mathrm{C}$ & $-0.016(0.051)$ \\
\hline Housing prices & $-0.414 * * *(0.122)$ \\
\hline Adjusted R ${ }^{2}$ & 0.481 \\
\hline F-statistic & 47.294 \\
\hline Log likelihood & -2185.830 \\
\hline
\end{tabular}

Note: $* * \mathrm{p}<0.05$ and $* * * \mathrm{p}<0.01$, standard errors are in brackets. 
Table 5: Panel Long term results for real estate and construction sectors capital flows, 1995Q1-2017Q4

\begin{tabular}{|c|c|c|c|c|}
\hline Long-term relationship: & \multicolumn{5}{|c|}{$\begin{array}{c}\text { Ronstruction sector } \\
\text { 1995Q1-2017Q4 }\end{array}$} \\
\hline variables & Eq1 & Eq2 & Eq1 & Eq2 \\
\hline Capital flows -Real Estate (-1) & 1.000 & 0.000 & $==$ & $==$ \\
\hline Capital flows-construction (-1) & $==$ & $==$ & 1.000 & 0.000 \\
\hline GDP growth rate (-1) & 0.000 & 1.000 & 0.000 & 1.000 \\
\hline M3(-1) & $\begin{array}{c}-1.758^{* * *} \\
(0.505)\end{array}$ & NS & $\begin{array}{c}-0.880^{* * *} \\
(0.156)\end{array}$ & NS \\
\hline Real interest rate (-1) & $-0.927^{* *}$ & $\begin{array}{c}0.917^{* *} \\
(0.407)\end{array}$ & $\begin{array}{c}0.258^{* *} \\
(0.118)\end{array}$ & \multirow{2}{*}{$\mathrm{NS}$} \\
\hline Country risk (-1) & $\begin{array}{c}(0.787) \\
(0.395)\end{array}$ & $\begin{array}{c}-0.853^{* *} \\
(0.416)\end{array}$ & $\mathrm{NS}$ & $\mathrm{NS}$ \\
\hline C & 0.077 & -0.026 & 0.0549 & -0.015 \\
\hline
\end{tabular}

Note: $* * \mathrm{p}<0.05$ and $* * * \mathrm{p}<0.01$, standard errors are in brackets. NS=Not Statistically Significant. 
Table 6: ECM results for real estate services and construction sectors capital flows

\begin{tabular}{|c|c|c|c|c|}
\hline Error Correction Model: & \multicolumn{2}{|c|}{$\begin{array}{c}\text { Real estate services } \\
\text { D(CF_RE })\end{array}$} & \multicolumn{2}{|c|}{$\begin{array}{l}\text { Construction } \\
\text { D(CF CON })\end{array}$} \\
\hline se & $\beta_{\mathrm{i}}^{*}$ & $\beta_{\mathrm{i}}$ & $\beta_{\mathrm{i}}^{*}$ & $\beta_{\mathrm{i}}$ \\
\hline CointEq1 & $\begin{array}{c}-0.643 * * * \\
(0.199)\end{array}$ & & $\begin{array}{l}-1.214 \\
(0.402)\end{array}$ & \\
\hline CointEq2 & $\begin{array}{c}-0.568 * * * \\
(0.170)\end{array}$ & & $\begin{array}{l}-0.097 \\
(0.275)\end{array}$ & \\
\hline$\Delta$ capital flows-real estate ${ }_{t-5}$ & $\begin{array}{c}-0.471 * * * \\
(0.116)\end{array}$ & -0.471 & & \\
\hline$\Delta$ GDP growth rate $\mathrm{t}_{\mathrm{t}-1}$ & $\begin{array}{c}1.606^{* * * *} \\
(0.394)\end{array}$ & $13.2 * 10^{-6}$ & & \\
\hline$\Delta \mathrm{GDP}$ growth rate $\mathrm{t}_{\mathrm{t}-5}$ & $\begin{array}{l}0.921 * * * \\
(0.379)\end{array}$ & $7.6^{*} 10^{-6}$ & & \\
\hline$\Delta \mathrm{M} 3_{\mathrm{t}-4}$ & $\begin{array}{c}4.617 * * \\
(2.344)\end{array}$ & 4.422 & & \\
\hline$\Delta$ Real interest rate $_{\mathrm{t}-3}$ & $\begin{array}{c}-0.643^{* *} \\
(0.285)\end{array}$ & $-4.1 * 10^{-6}$ & & \\
\hline$\Delta$ Real interest rate ${ }_{\mathrm{t}-4}$ & 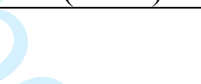 & & $\begin{array}{l}0.948 * * \\
(0.411)\end{array}$ & $4.4 * 10^{-6}$ \\
\hline Exogenous variable: & & & & \\
\hline Housing prices $_{t}$ & $\begin{array}{c}-0.712 * * * \\
(0.307)\end{array}$ & $-1.088^{*} 10^{-3}$ & $\begin{array}{c}-1.249 * * * \\
(0.408)\end{array}$ & $-1.373 * 10^{-3}$ \\
\hline Adjusted R ${ }^{2}$ & 0.660 & & 0.512 & \\
\hline F-statistic & 6.694 & & 4.075 & \\
\hline Log likelihood & -73.877 & P & -99.582 & \\
\hline
\end{tabular}

Note: $* * \mathrm{p}<0.05$ and $* * * \mathrm{p}<0.01$, standard errors are in brackets. The blank cells are not statistically significant. $\beta_{\mathrm{i}}{ }^{*}$ are the regression coefficients of standardized variables, and $\beta_{\mathrm{i}}$ are coefficients after transformation by using the formula $\beta_{i}^{*}=\beta_{i}\left(\frac{S x_{i}}{S y_{i}}\right)$, where $S x_{i}$ are the standard deviations for each dependent variable and $S y_{i}$ are the standard deviations for each independent variable (Gujarati and Porter, 2009). Dependent variable was measure in thousands of euros before normalization. The transformed parameters are interpreted according to it.

Table 7: Pooled EGLS results

\begin{tabular}{|c|c|c|}
\hline \multicolumn{2}{|c|}{ Dependent Variable: CF (total capital flows) } & $8+20$ \\
\hline \begin{tabular}{|l|} 
Variable \\
\end{tabular} & Coefficient & Std. Error \\
\hline \multicolumn{3}{|c|}{ Common parameters for all capital flows } \\
\hline Real interest rate & -0.027 & 0.033 \\
\hline Country risk & -0.008 & 0.037 \\
\hline Exchange rate & 0.038 & 0.042 \\
\hline \multicolumn{3}{|c|}{ Specific parameters varying by sector receiving capital flows } \\
\hline 1 - GDP growth rate & $0.356^{* * *}$ & 0.115 \\
\hline 6-GDP growth rate & $0.355 * * *$ & 0.116 \\
\hline 12-GDP growth rate & $0.261 * *$ & 0.105 \\
\hline 17-GDP growth rate & $-0.305^{* * *}$ & 0.120 \\
\hline $1-\mathrm{M} 3$ & $1.111 * * *$ & 0.202 \\
\hline $3-\mathrm{M} 3$ & $0.484 * *$ & 0.219 \\
\hline $5-\mathrm{M} 3$ & $0.490 * *$ & 0.227 \\
\hline 6-M3 & $0.990 * * *$ & 0.205 \\
\hline 9-M3 & $0.694 * * *$ & 0.221 \\
\hline $11-\mathrm{M} 3$ & $0.462 * *$ & 0.226 \\
\hline
\end{tabular}




\begin{tabular}{|c|c|c|}
\hline $12-\mathrm{M3}$ & $1.285 * * *$ & 0.185 \\
\hline $13-\mathrm{M} 3$ & $0.574 * * *$ & 0.226 \\
\hline $15-\mathrm{M} 3$ & $0.443 * *$ & 0.230 \\
\hline $16-\mathrm{M} 3$ & $-0.476^{* *}$ & 0.229 \\
\hline $17-\mathrm{M} 3$ & $0.415^{* *}$ & 0.212 \\
\hline $1-$ Housing prices & $-0.788 * * *$ & 0.189 \\
\hline 3-Housing prices & $-0.527 * * *$ & 0.205 \\
\hline 6-Housing prices & $-0.577 * * *$ & 0.193 \\
\hline 9-Housing prices & $-0.461 * *$ & 0.207 \\
\hline 10 - Housing prices & $-0.426^{* *}$ & 0.209 \\
\hline 12-Housing prices & $-0.839 * * *$ & 0.175 \\
\hline 13-Housing prices & $-0.420 * *$ & 0.211 \\
\hline 17-Housing prices & $-0.516^{* * *}$ & 0.198 \\
\hline \multicolumn{3}{|c|}{ Weighted Statistics } \\
\hline Adjusted R ${ }^{2}$ & \multicolumn{2}{|c|}{0.087} \\
\hline Sum squared resid & \multicolumn{2}{|c|}{1463.2} \\
\hline Durbin-Watson stat & \multicolumn{2}{|c|}{2.089} \\
\hline \multicolumn{3}{|c|}{ Unweighted Statistics } \\
\hline $\mathbf{R}^{2}$ & \multicolumn{2}{|c|}{0.106} \\
\hline Durbin-Watson stat & \multicolumn{2}{|c|}{2.076} \\
\hline \multicolumn{3}{|c|}{$\mathrm{N}=1656$, from 1995Q1-2017Q4, cross-section weights are included } \\
\hline
\end{tabular}

Note: 6-construction; 12 -real estate services. ${ }^{* *} \mathrm{p}<0.05$ and $* * * \mathrm{p}<0.01$. 
Appendix: STATISTICAL ANNEX

Table A-I: Full Pool-VECM results for all capital flows

\begin{tabular}{|c|c|c|c|c|c|}
\hline Error Correction: & $\Delta \mathrm{CF}$ & $\Delta$ GDP_SP & $\Delta \mathbf{M 3}$ & $\Delta$ RIR_SP & $\triangle C R$ SP \\
\hline Equations & (1) & (2) & (3) & (4) & (5) \\
\hline CointEq1-capital flows & $\begin{array}{c}-0.869 * * * \\
(0.060)\end{array}$ & & & & \\
\hline CointEq2-GDP growth rate & & $\begin{array}{c}-0.054 * * * \\
(0.021) \\
\end{array}$ & $\begin{array}{c}0.042 * * * \\
(0.002)\end{array}$ & & $\begin{array}{c}0.093 * * * \\
(0.013)\end{array}$ \\
\hline CointEq3- M3 & $\begin{array}{l}0.333 * * * \\
(0.042)\end{array}$ & & $\begin{array}{c}-0.014 * * * \\
(0.001)\end{array}$ & $\begin{array}{c}-0.074 * * * \\
(0.010)\end{array}$ & $\begin{array}{c}0.072 * * * \\
(0.006)\end{array}$ \\
\hline $\begin{array}{c}\text { CointEq4 -Real Interest } \\
\text { Rate }\end{array}$ & & $\begin{array}{l}-0.072 * * * \\
(0.011)\end{array}$ & $\begin{array}{c}-0.009 * * * \\
(0.001)\end{array}$ & $\begin{array}{c}-0.146 * * * \\
(0.012)\end{array}$ & $\begin{array}{c}0.070 * * * \\
(0.007)\end{array}$ \\
\hline$\Delta$ capital flows ${ }_{t-5}$ & & $\begin{array}{c}-0.012 * * \\
(0.006)\end{array}$ & & & \\
\hline$\Delta$ GDP growth rate ${ }_{t-1}$ & $\begin{array}{c}0.410 * * * \\
(0.144)\end{array}$ & & $\begin{array}{c}-0.029 * * * \\
(0.004)\end{array}$ & $\begin{array}{c}-0.106 * * * \\
(0.035)\end{array}$ & \\
\hline$\Delta$ GDP growth rate $\mathrm{t}_{-2}$ & & $\begin{array}{c}-0.075 * * * \\
(0.030)\end{array}$ & & & $\begin{array}{c}-0.127 * * * \\
(0.019)\end{array}$ \\
\hline$\Delta$ GDP growth rate ${ }_{t-3}$ & & $\begin{array}{c}0.166^{* * *} \\
(0.028)\end{array}$ & $\begin{array}{c}0.015 * * * \\
(0.003)\end{array}$ & & \\
\hline$\Delta$ GDP growth rate $t_{t-4}$ & & $\begin{array}{c}-0.175^{* * * *} \\
(0.026)\end{array}$ & $\begin{array}{c}-0.018 * * * \\
(0.003) \\
\end{array}$ & $\begin{array}{c}0.112 * * * \\
(0.029)\end{array}$ & $\begin{array}{c}-0.143 * * * \\
(0.017) \\
\end{array}$ \\
\hline$\Delta$ GDP growth rate $t_{t-5}$ & $\begin{array}{c}0.432 * * * \\
(0.122)\end{array}$ & $\begin{array}{c}-0.158 * * * \\
(0.028)\end{array}$ & $\begin{array}{c}0.013 * * * \\
(0.003)\end{array}$ & & \\
\hline$\Delta \mathrm{M} 3_{\mathrm{t}-1}$ & $\begin{array}{c}1.979 * * \\
(0.839)\end{array}$ & & $\begin{array}{c}-0.066^{* * *} \\
(0.024)\end{array}$ & $\begin{array}{c}1.155^{* * *} * \\
(0.208)\end{array}$ & $\begin{array}{c}-0.565 * * * \\
(0.123)\end{array}$ \\
\hline$\Delta \mathrm{M} 3_{\mathrm{t}-2}$ & & & $\begin{array}{l}0.258 * * * \\
(0.024)\end{array}$ & & \\
\hline$\Delta \mathrm{M} 3_{\mathrm{t}-3}$ & & $\begin{array}{c}-1.900 * * * \\
(0.199)\end{array}$ & & $\begin{array}{c}-1.394 * * * \\
(0.215) \\
\end{array}$ & $\begin{array}{c}-0.469 * * * \\
(0.127)\end{array}$ \\
\hline$\Delta \mathrm{M} 3_{\mathrm{t}-4}$ & $\begin{array}{c}1.564 * * \\
(0.789)\end{array}$ & $\begin{array}{c}-1.203^{* * *} \\
(0.181) \\
\end{array}$ & $\begin{array}{c}0.231 * * * \\
(0.023) \\
\end{array}$ & $\begin{array}{c}0.887 * * * \\
(0.196) \\
\end{array}$ & $\begin{array}{c}-1.560 * * * \\
(0.116)\end{array}$ \\
\hline$\Delta \mathrm{M} 3_{\mathrm{t}-5}$ & & & $\begin{array}{c}-0.077 * * * \\
(0.020) \\
\end{array}$ & & $\begin{array}{c}-0.814 * * * \\
(0.103)\end{array}$ \\
\hline$\Delta$ real interest rate ${ }_{\mathrm{t}-1}$ & & $\begin{array}{c}-0.108 * * * \\
(0.022)\end{array}$ & $\begin{array}{c}0.022 * * * \\
(0.002)\end{array}$ & $\begin{array}{c}0.238 * * * \\
(0.024)\end{array}$ & \\
\hline$\Delta$ real interest rate ${ }_{t-2}$ & & $\begin{array}{c}0.183 * * * \\
(0.021)\end{array}$ & 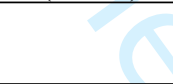 & & $\begin{array}{c}-0.090 * * * \\
(0.014)\end{array}$ \\
\hline$\Delta$ real interest rate ${ }_{t-3}$ & & $\begin{array}{c}0.059 * * * \\
(0.022)\end{array}$ & $\begin{array}{c}0.024 * * * \\
(0.002) \\
\end{array}$ & $10=0$ & $\begin{array}{c}-0.036^{* * *} * \\
(0.014)\end{array}$ \\
\hline$\Delta$ real interest rate ${ }_{\mathrm{t}-4}$ & & $\begin{array}{c}0.064 * * * \\
(0.023)\end{array}$ & & $\begin{array}{c}-0.311 * * * \\
(0.025)\end{array}$ & $\begin{array}{l}0.034 * * \\
(0.014)\end{array}$ \\
\hline$\Delta$ real interest rate ${ }_{t-5}$ & & $\begin{array}{c}0.133 * * * \\
(0.024)\end{array}$ & $\begin{array}{c}0.050 * * * \\
(0.003)\end{array}$ & $\begin{array}{c}0.096 * * * \\
(0.026)\end{array}$ & $\begin{array}{c}-0.151^{* * *} \\
(0.015) \\
\end{array}$ \\
\hline$\Delta$ country risk $_{\mathrm{t}-1}$ & & $\begin{array}{c}-0.245^{* * *} \\
(0.042)\end{array}$ & $\begin{array}{c}-0.045^{* * *} \\
(0.005) \\
\end{array}$ & $\begin{array}{c}-0.089 * * \\
(0.045) \\
\end{array}$ & $\begin{array}{c}0.265^{* * *} \\
(0.027) \\
\end{array}$ \\
\hline$\Delta$ country risk $_{\mathrm{t}-2}$ & & $\begin{array}{c}-0.340 * * * \\
(0.040)\end{array}$ & $\begin{array}{c}0.086^{* * *} \\
(0.005)\end{array}$ & $\begin{array}{c}-0.182 * * * \\
(0.043)\end{array}$ & $\begin{array}{c}-0.217 * * * \\
(0.025)\end{array}$ \\
\hline$\Delta$ country risk $_{\mathrm{t}-3}$ & & $\begin{array}{c}-0.121 * * * \\
(0.041)\end{array}$ & $\begin{array}{c}-0.011^{* *} \\
(0.005)\end{array}$ & $\begin{array}{c}-0.293 * * * \\
(0.044)\end{array}$ & $\begin{array}{c}0.419 * * * \\
(0.026)\end{array}$ \\
\hline$\Delta$ country risk $\mathrm{t}_{\mathrm{t}-4}$ & & $\begin{array}{c}-0.216^{* * *} \\
(0.044)\end{array}$ & $\begin{array}{c}-0.034 * * * \\
(0.005) \\
\end{array}$ & $\begin{array}{c}-0.232 * * * \\
(0.048)\end{array}$ & $\begin{array}{c}-0.158 * * * \\
(0.028) \\
\end{array}$ \\
\hline$\Delta$ country risk ${ }_{\mathrm{t}-5}$ & & $\begin{array}{c}0.148 * * * \\
(0.044)\end{array}$ & $\begin{array}{c}0.026 * * * \\
(0.005) \\
\end{array}$ & $\begin{array}{c}0.262 * * * \\
(0.048) \\
\end{array}$ & $\begin{array}{c}0.120 * * * \\
(0.028) \\
\end{array}$ \\
\hline $\mathrm{C}$ & $\begin{array}{l}-0.016 \\
(0.051)\end{array}$ & $\begin{array}{c}0.077 * * * \\
(0.011)\end{array}$ & $\begin{array}{c}0.023 * * * \\
(0.001)\end{array}$ & $\begin{array}{c}-0.080 * * * \\
(0.012)\end{array}$ & $\begin{array}{c}0.073 * * * \\
(0.007)\end{array}$ \\
\hline
\end{tabular}




\begin{tabular}{|l|c|c|c|c|c|}
\hline \multicolumn{1}{|c|}{ Exchange rate $_{\mathrm{t}}$} & & & $\begin{array}{c}0.008 * * * \\
(0.001)\end{array}$ & $\begin{array}{c}0.038^{* * *} \\
(0.013)\end{array}$ & $\begin{array}{c}-0.038^{* * *} \\
(0.007)\end{array}$ \\
\hline \multicolumn{1}{|c|}{ Housing prices $_{\mathrm{t}}$} & $\begin{array}{c}-0.414 * * * \\
(0.122)\end{array}$ & & $\begin{array}{c}0.018 * * * \\
(0.003)\end{array}$ & & $\begin{array}{c}0.134 * * * \\
(0.018)\end{array}$ \\
\hline Adjusted R & 0.481 & 0.464 & 0.766 & 0.397 & 0.552 \\
\hline F-statistic & 47.294 & 44.348 & 164.774 & 33.885 & 62.558 \\
\hline Log likelihood & -2185.830 & 85.815 & 3283.768 & -31.830 & 781.350 \\
\hline
\end{tabular}

Note: $* *$ p-value $<0.05$ and $* * *$ p-value $<0.01$, standard errors are in brackets. The blank cells are not statistically significant. This table shows economic reactions in the model. Changes in capital flows are only statistically significant in the fifth lag in the GDP growth short term model. The lack of significance in the (3) model with M3 suggests that the direction of a relationship between capital flows and M3 has just one sense (from M3 to capital flows) with the opposite being not true. 


\section{FIGURES}

\section{Figure 1: QUARTERLY GLOBAL REAL ESTATE TRANSACTION VOLUME, 2005Q2-2018Q2 \\ (In billions U.S. dollars)}

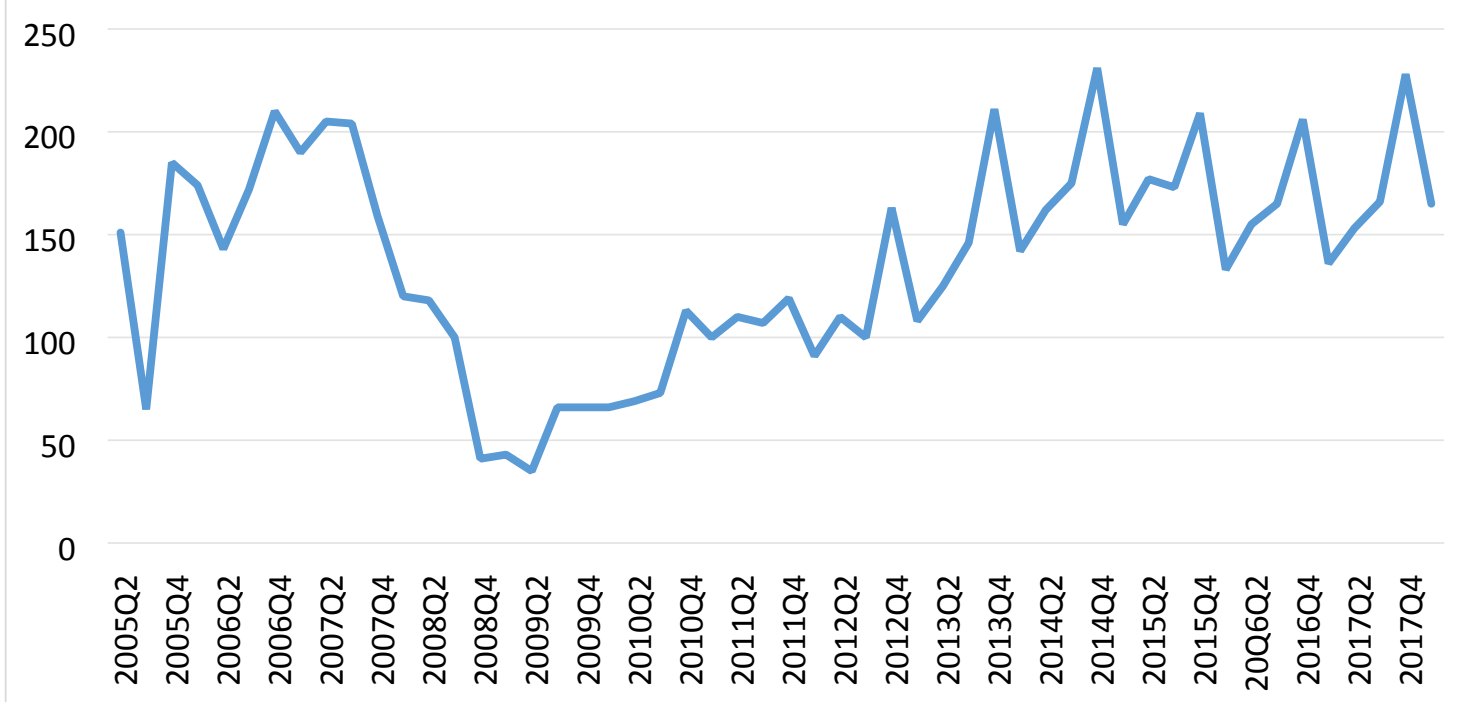

Source: JLL, available at: https://www.theinvestor.jll/gcf/. 
Figure 2: INTERNATIONAL INVESTMENT TO SPANISH REAL ESTATE SECTOR, 1995Q1-2017Q4

(In billions of euros)

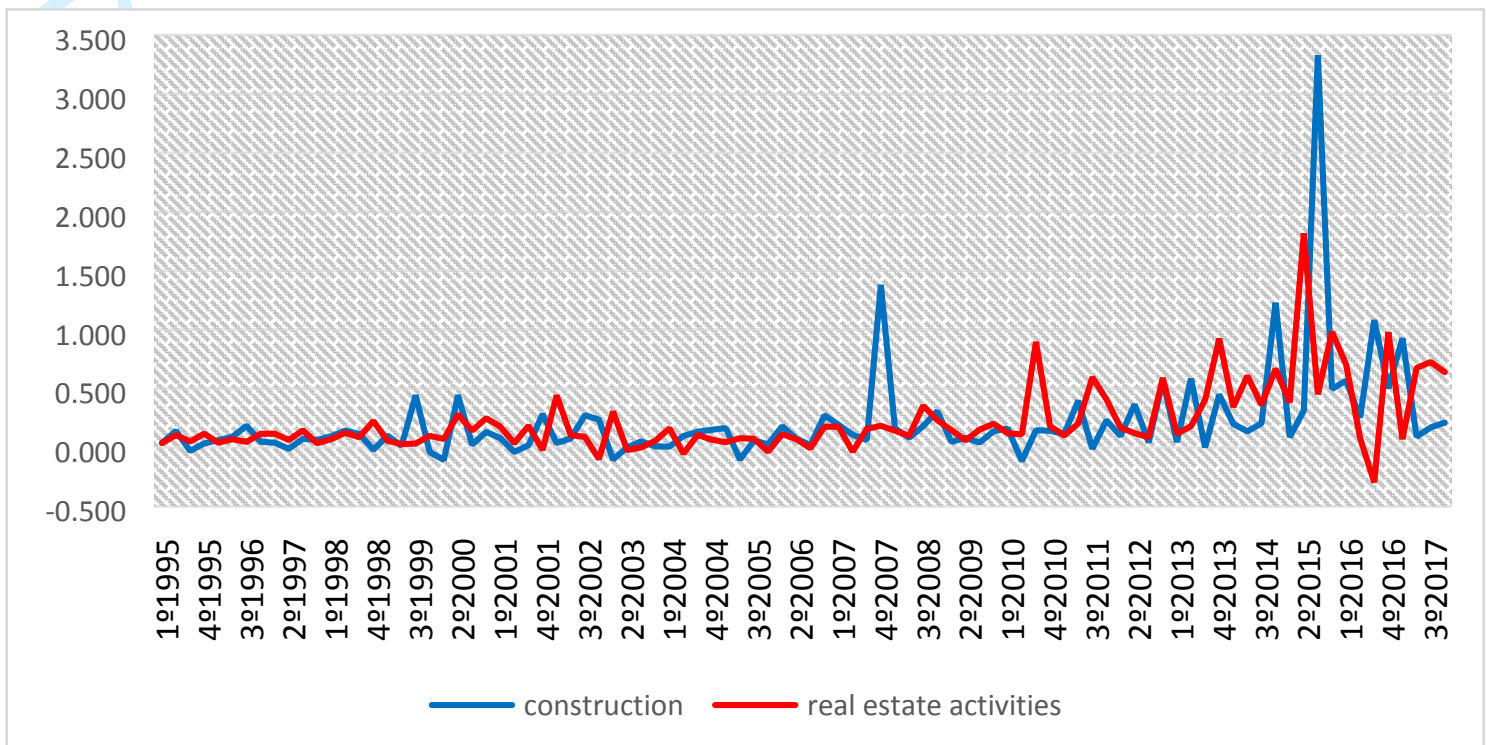

Source: Ministry of industry, trade and tourism of Spain, available at: http://datainvex.comercio.es/principal invex.aspx. 